\title{
ADDITIVE MANUFACTURING (3D PRINTING) IN TECHNICAL FASHION INDUSTRY APPLICATIONS
}

\author{
Ezgi DiLEK', Muhammed İkbal YILDIRIM², Muhammet UZUN3,4,*
}
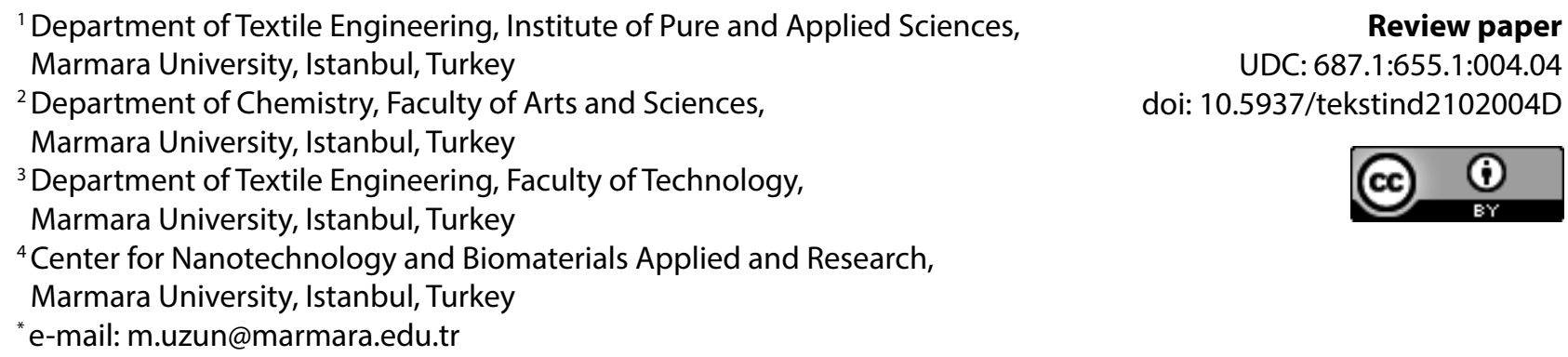

Abstract: With the development of recent technologies, novel design strategies possibilities increase day by day. $3 D$ printing technologies, which are also known as the additive manufacturing, are announced as the technology of today as well as the future. The aim of this study is to review current literature in terms of the types of $3 D$ printers, the raw materials, the manufacturing processes, and design examples. It is also aimed to highlight some of the well-known brands and designers in the fashion industry which employed the 3D printers to develop their fashionable structures. The main advantage of the 3D printing technologies is to ease of the creating own design without needing help. Everyone can now be their own designer and manufacturer with this technology, thanks to 3D printers, and in a few hours, they can produce the product anywhere within the preferred color and model.

Keywords: Additive manufacturing (3D), technical fashion, polylactic acid, acrylonitrile butadiene styrene.

\section{PRIMENA PROIZVODNJE ADITIVA (3D ŠTAMPA) U TEHNIČKOJ MODNOJ INDUSTRIJI}

\begin{abstract}
Apstrakt: Sa razvojem novih tehnologija, novih strategija dizajna mogućnosti svakim danom bivaju sve veće. Tehnologija 3D štampe, takođe poznata kao proizvodnja aditiva, predstavljena je kao tehnologija sadašnjosti ali i budućnosti. Cilj ovog istraživanja ogleda se u pregledu trenutne literature po pitanju tipa 3D štampača, sirovih materijala, proizvodnih procesa i primera dizajna. Cilj je takođe da se istaknu neki od dobro poznatih brendova i dizajnera u modnoj industriji koji primenjuju 3D štampače za razvoj modnih struktura. Osnovna prednost tehnologije 3D štampe je olakšano kreiranje sopstvenih dizajna bez potrebe za dodatnom pomoći. Zahvaljujući 3D štampačima sada svako može biti dizajner i proizvođač, a za nekoliko sati može proizvesti proizvod bilo gde u okviru željene boje i modela.
\end{abstract}

Ključne reči: proizvodnja aditiva (3D), tehnička moda, polilaktična kiselina, akrilonitril butadien stiren.

\section{INTRODUCTION}

Fashion is the process by which a product becomes popular within a given time frame and encompasses traditions or styles. Fashion is first accepted by a few people, and in course of time it begins to be accepted by everyone. Then its popularity wanes [1, 2]. On the other hand, fashion design is a general term used for the work done by using the information required for design in order to create trend pieces created with this interest. "Haute couture" and "ready-to-wear" are the two types of fashion design [3]. Haute couture has a French origin, it means personalized sewing. In haute couture parts, the product to be designed are made with great care and attention by the hands of workmanship, using expensive and high-quality fab- 
rics in the production, based on the person's request and the size of the person [4]. Ready-to-wear, on the other hand, is known as mass production and it is the products in stores with lower costs [5].

With the developing technology, fashion changes and develops every day. In the 18th century, clothing sector production technologies, methods and materials changed due to industrialization. With these technological developments in the fashion industry, fashion designers have also been affected by this situation. It may be impossible for the designer to embody his original thought and imagination with old technology, but with the developing technology, these impossibilities have disappeared. With the elimination of these impossibilities in design and the realization of the extraordinary designs made, it both inspires other designers and allows the imagination of designers to develop $[6,7,8,9]$. With 3D printers, which are trending in today's technologies and will become widely available in the future, everyone will be their own designer, and they will have the opportunity to make free designs as they wish with fast and low costs [10]. 3D printers, also known as additive manufacturers, address a large part of the population. It is the technology of the future and is used in the production of clothes (shoes, bags, dresses, skirts, etc.) in the fashion sector. In short, 3D printers are capable of producing designer clothes designed by the fashion designer or people in line with fashion trends within hours $[6,7,8,9]$. This research examines the innovations and developments brought by 3D printers, one of the developing technology branches, in the field of fashion (clothing, shoes, bags, etc.). The main purpose is informed to designers and manufacturers who are interested in this subject by conducting a research based on observations about the use of 3D printers in the field of fashion as well as in many areas in daily life. Domestic and foreign sources were examined in the research.

\subsection{D Printers (Additive Manufacturing) and Personalization}

3D printers, which are thought to be used more in the future, are used in the field of fashion in daily life, as well as shoes, bags, jewelry and so on. It is used in many areas [11]. There are many reasons to abandon mold production and switch to this technology where CAD software is intense. Some of them are very risky and difficult to remove the fine details as a mold in the production made by the molding method. On the contrary, in the designs made in digital environment with CAD software, very fine detailed patterns and fashion products that exceed our imagination can be easily produced. At the same time, the molding method is costly and requires more time-intensive work $[12,13,14]$. With the molding method, which is the traditional method, it is quite expensive in personalized haute couture production. Errors made in design with molding may be situations where the product should be started from scratch, in this case it is a situation to the detriment of the designer. Because the quality and cost of the fabric used in the production of haute couture (personalized design) products are high and the processing details are meticulously made [9]. In addition, 3D printing is sustainable. The use of 3D printing in production can help reduce waste [15].

With 3D printers, which are known as the technology of the future, as a rival to all these methods, it is now possible to produce shoes suitable for the color of our clothes or clothes suitable for the color and pattern of our bag. The fashion industry, which is in a continuous cycle with 3D printers, takes a different path. With the development and cheapness of home 3D printers, we will be able to produce all the impossible and wearable fashion products at home, in the office, in any place where we can reach a 3D printer, in any size, colors, patterns and imagination. This

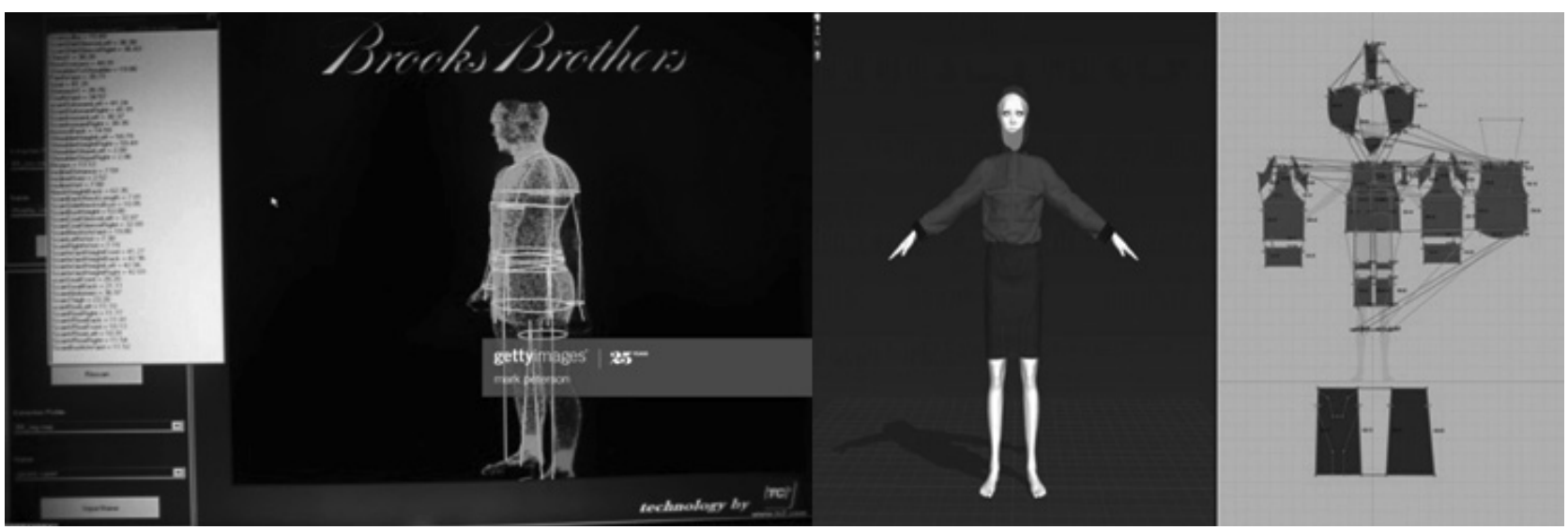

Figure 1: 3D body scanning and model creation system of the Broosk Brothers company [9] 

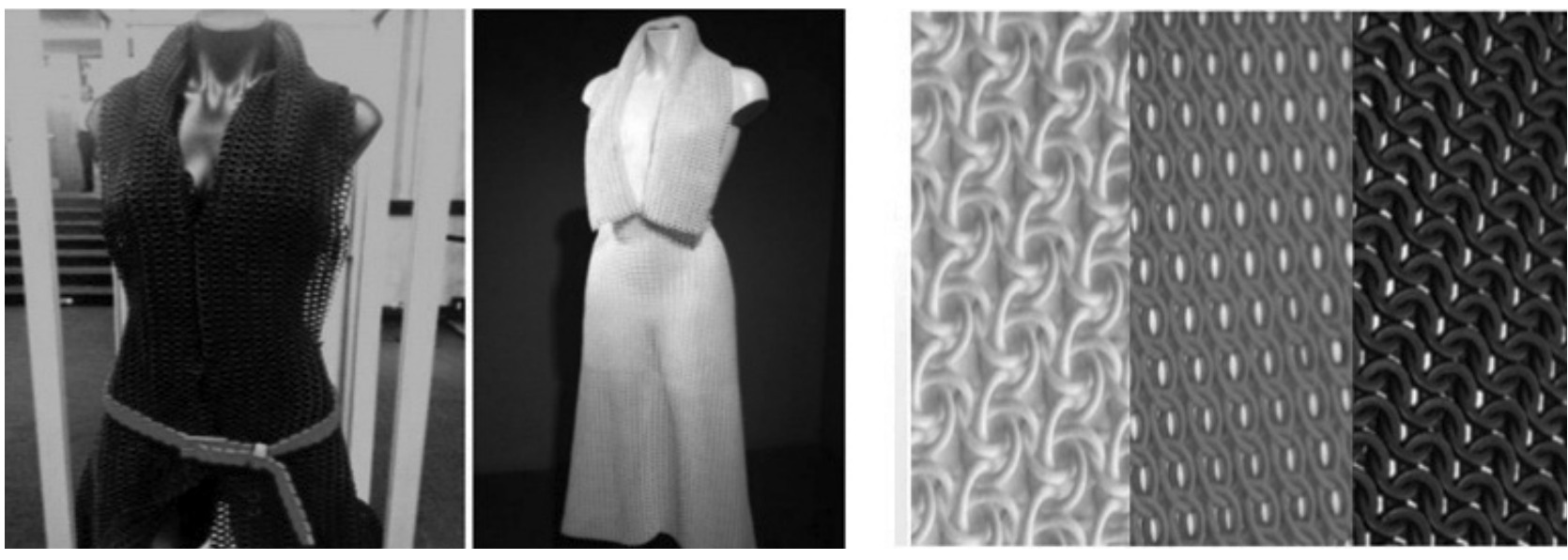

Figure 2: Janne Kyttanen, black draped dress and various designed surfaces [7, 18]

will make it possible for the consumer to become a producer in the future $[15,16]$. Applications including 3D body scanners are also used for personalization. 3D scanners create a digital copy of the outside of the human body. With this digital copy, clothes are produced according to body sizes with body scanning. With 3D body scanning technology, refund problems can be eliminated [17]. In 2001, the Brooks Brothers company introduced a digital tailoring system (Figure 1) where people called "Digital Tailoring" can create suits, jackets, trousers, and shirts [9].

As seen in the examples, manufacturers have made great strides in the field of personalization to produce personalized products that match the body size, color, and taste of consumers. The "black drape dress" (Figure 2) was developed by Jiri Evenhuis and Janne Kyttanen, one of the first to produce with 3D printers. Laser sintering (DMSL) was used in the production phase of the suit. For machine control, the product produced with the slicing software consists of separate parts. Today, the dress is a permanent part of many museums such as The Museum at FIT in New York City [7, 9, 18].

Another example of customization with 3D printers is New York designer Michael Schmidt and architect Francis Bitonti created a 3D printed dress for dancer Dita von Teese. The personalized design product designed by the designer Michael Schmidt was produced by Francis Bitonti using Laser sintering (SLS) method. In production, it is based on the transformation of plastic material as a material into a layered structure with laser sinter. It is articulated to each other to create a mesh image with hard plastic material. Spirals based on the golden ratio were applied to the computer image of the dancer Dita von Teese's body. With this advantage, the dress fits on the person and can easily perform the waist movement. There is a silk corset under the dress. 17 pieces of products were produced with a 3D printer and the pieces were attached to the suit by hand. The dress is embellished with 12,000 Swarovski crystals on it. Finally, the dress has been carefully polished to shine $[7,19]$.

$3 \mathrm{D}$ printer undertakes the process of converting the designed product into tangible through 3D printer after the design is made with CAD systems. It is thought that personalization in 3D printers and making everyone their own designer can help reduce the consumption of ready-to-wear industry and non-recyclable textile products. Today, materials used in 3D printers are increasing day by day. The materials used are synthetic based. It is hoped that natural materials will be developed in the coming years. Finally, personalization in 3D printers is also a step towards preventing waste in consumption. In this way, waste is eliminated, and it becomes possible to produce clothes suitable for every budget.

\subsection{D Printer and Its Emergence}

$3 \mathrm{D}$ printer (printer) is based on the principle that the product, which is designed with computer-aided CAD software systems, is transferred to 3D printers in a computer environment without using any mold material and paper, pen, and the printer creates a 3-dimensional product by gradually adding it in layers. On the other hand, 3D scanner enables an object in tangible form to be made visible in the computer environment by pouring it into numerical data. In addition, changes can be made on the object transferred to the computer environment with the scanner. The process in the scanner is done by laser or optical methods. By sending light to the object to be scanned, the object is digitally transferred to the computer and made visible. Today, this process is carried out within minutes $[20,21]$. 
3D printers came into our lives in the 1980s and their effectiveness has been increasing for about 20 years. The reason for this is that the advertising opportunity has increased, and it has become easier to explain the contribution of 3D printers to our lives to wider audiences [22]. In 1984, Charles Hull invented a technology based on the hardening of the resin in liquid form layer by layer with UV. This method is the working principle of SLA technology. It patented this technology in 1986 and in 1988 established 3D systems, one of the largest 3D printer companies. In 1988, Scott Crump added a layer of silicone layer by layer with a silicone gun to make a toy frog for his little daughter, and his trial was successful. This method has formed the basics of FDM technology [23]. Currently, the $3 \mathrm{D}$ printing market is valued at US $\$ 13.7$ billion in 2020 and is expected to reach us $\$ 63.46$ billion by 2026 with a CAGR of $29.48 \%$ during the forecast period (2021 - 2026) [24].

\section{3D PRINTER PRODUCTION METHODS USED IN THE FASHION INDUSTRY}

As a result of the slow operation of commercial 3D printers, it provides products for a long time, but this disadvantage is eliminated due to the reduction of the length of the textile process chain. There is no need to perform operations such as weaving, dyeing, cutting, sewing for 3D printed clothes. In addition, there is a serious decrease in expenses such as transportation, energy, and salary [25]. 3D printers in the fashion industry address 2 purposes. The first of these is that the garment can be produced as a whole. The size of the garment to be produced also depends on the size of the printer. The latter is based on creating surfaces with alternative parts produced by a 3D printer next to woven or knitted surfaces. In other words, the product is produced in pieces and then combined with various methods [11].

The design studio named Nervous System has removed the restrictions in movement with the garment hinges produced with a 3D printer and in one piece. It can also be said that the dress behaves like a fabric since it does not restrict movement and is very comfortable. The company named the production method of this hinged dress "Kinematic". Complex images, numerical operations and a series of operations are eventually revealed, where the surface is created by interlocking the components and the production is achieved exponentially in the form of a ball. This ball-looking complex structure comes across as a whole dress assembled after it comes out of its 3D printer. Besides the dress, the design company named Nervous system produces in one piece by kinematic method; there are many products such as belts, corsets, jewelry, skirts (Figure 3). There are many products, all of them are produced in a folded manner to be produced on the production table of the 3D printer as in the production method and are removed from the machine as one piece intertwined with hinges [26].

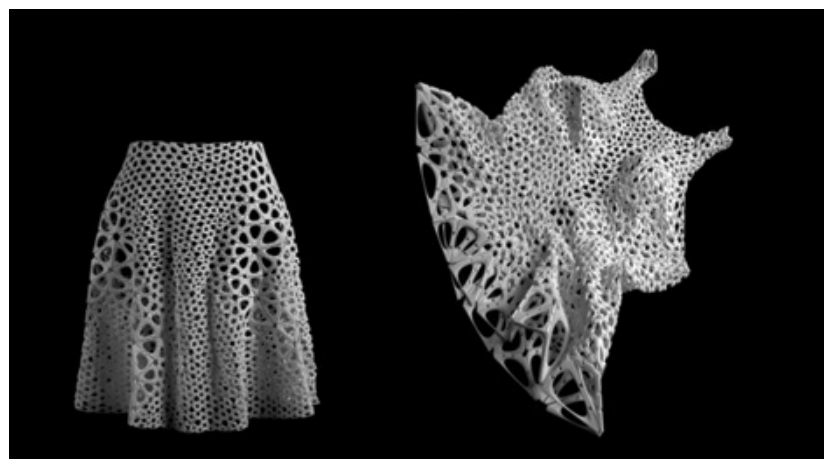

Figure 3: Example of skirt and blouse designed with kinematic production [26]

For five years, shoe manufacturers around the world, such as Nike, Adidas, and Reebok, have been leading names in the $3 \mathrm{D}$ printing method. To this day, companies only use 3D printers to prepare prototypes, while now insoles, midsoles, and sandals can also be used in the production phase. Companies can use 3D printers to make a wide range of designs (Figure 4) [27].

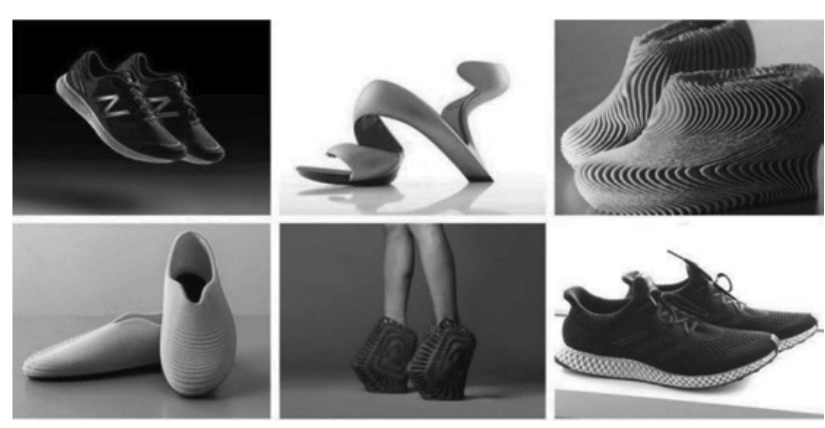

Figure 4: 3D printed shoe samples [27]

SLS (Selective Laser Sintering), FDM (Fused Deposition Modeling), Stereolithography (SLA), Polyjet, Binder jetting are often used in the production of products in the fashion industry $[11,28]$.

\subsection{SLS (Selective Laser Sintering)}

The foundations of the SLS (Selective Laser Sintering) method are based on the principle of hardening resin materials in layers with the help of laser by Charles Hull. With this method, it has patented the Stereolithography technology. SLS method is also known as fusion in powder ground [23]. The basic production in the SLS method is based on the hardening 
of the powder material by heat and pressure. In other words, this process is repeated in layers after the powder material put on the foundation is hardened by laser beams. Eventually, the product is obtained. Thermoplastic polymers are used as the main raw material in SLS printing. The laser beam provides the hardening of the dust particles, called the" sintering " process. In the SLS method, it is used in various fields, as it can create complex shapes without the need for a Support Element and create complete products. At the same time, powders that are dissolved can be reused. The difference between SLS method and FDM technology is that the parts are embedded in the powder used as raw material. Therefore, there is no need for support material. Since there is no support material, time loss for cleaning is eliminated and the resulting model is the finished product $[29,30]$.

In a construction platform where 3D material is produced, it consists of 6 parts a laser responsible for sintering, Galvano mirrors used to project and direct the laser beam to the correct printing positions, a reservoir platform that holds the dust and distributes it on the platform, a mechanical cylinder that emits and flattens the dust on the platform, and a material vessel that restores the powder material $[29,16]$. In the SLS system, advantages are gained from reasons such as material diversity, time saving, low cost due to tool-free production, low cost because no additional material is used in model formation, the product produced is hard and highly resistant, and has high resistance to chemicals. Having a porous structure is a disadvantage. Making complex designs and extraordinary detailing is possible. Model production can be made with SLS technology and prototype production can be carried out quickly and easily [31].

The collection called crystallization was presented to the consumer during the Amsterdam fashion week in 2010 by fashion designer Iris Van Herpen and architect Daniel Widrig. The sequel to the collection, the escape, was presented at Paris fashion week in early 2020. Escapism collection is to force production with $3 \mathrm{D}$ printers and show everyone what can be done. CAD software is used by making computer-aided designs. Flexible and lightweight fiber materials are used. Houte Couture products are manufactured in collaboration with New York-based Label MGX using the SLS method with polyamide-like materials [32].

\subsection{Fused Deposition Modeling (FDM)}

FDM technology is also known as melt-pile modeling. FDM technology, which was introduced by Scott Crump, the founder of Stratasys in 1980, is the most preferred method among other technologies with its easy operating system. FDM technology is used in approximately $70 \%$ of 3D printers worldwide. The application method of FDM technology is melted by bringing the thermoplastic material to the melting temperature with a nozzle that controls the temperature. The molten thermoplastic material is pushed into the head automatically. The material coming out of the head in a very thin state is laid on the printing table in layers and the model is formed. Many types of materials can be used in FDM printing, such as ABS, PLA (poly-lactic acid), TPU polycarbonate and nylon. In this system where thermoplastic materials are used, ABS and PLA materials are mostly preferred $[33,13,30]$. The materials used in FDM technology are recyclable and environmentally friendly. Along with all these, it is the method with the highest material strength. The variety of colors used in FDM technology is also quite high. But one of the problems with printers is precision and roughness. It can be used to make solid products, but its surfaces are rougher than those of SLS and/or SLA products. In FDM technology, the adhesion between layers is lower compared to SLA technology, so the upper layers apply pressure to the lower layers, helping to increase the adhesion rate. However, the lower layers will be compressed due to the weight of the upper layer, and errors in the printing of the modeling may occur, such as the lifting of edges, inaccuracies in the modeling of the layers, the shifting of the layers due to overlap, and the shrinkage of the lower layers. While the reasons are listed in this way, it cannot be said that surface behavior and sensitivity are high. FDM technology can be used in prototype construction, low-cost modeling, where precision and surface quality are not kept too high [11, 33, 34, 35].

To summarize briefly; The design product designed with CAD software is converted to stl format and converted into a format that the 3D printer can read. In modeling, it is decided whether there will be support material or not. The thermoplastic material to be used is added to the printer and the material is melted by heating up to the melting point thanks to the hot head. The working principle of the nozzle is based on the principle of repeating the process in layers by spraying the material in thin layers. At the same time, the distance between the head and the print tray is adjusted. The thermoplastic material is automatically pushed into the nozzle and the sprayed material solidifies with the nozzle. The movement of the printing tray is adjusted to be millimetric. Production is completed by repeating this process. If the support material is used after the end of the production, the support material is removed manually or with water 
and chemical material after production $[35,36]$. The schematic diagram of the FDM 3D printer is shown in Figure 5.

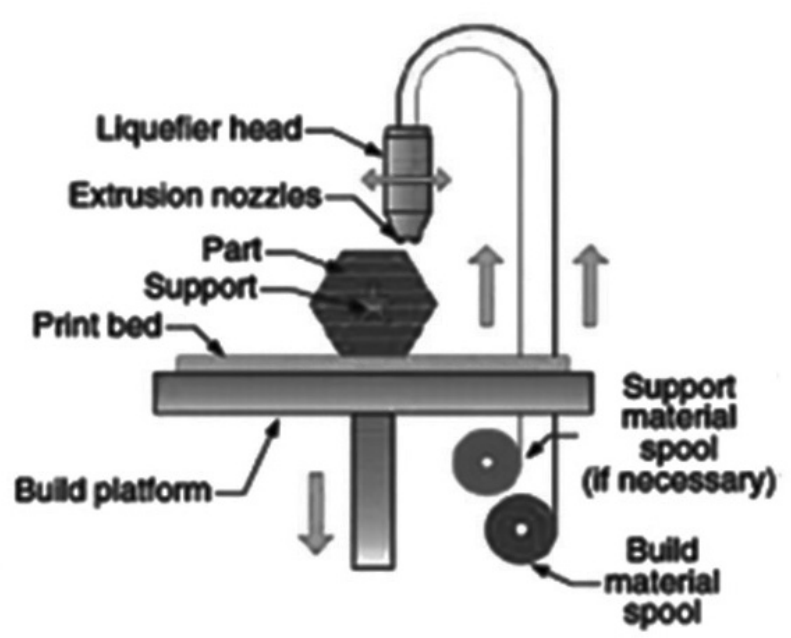

Figure 5: Schematic diagram of FDM 3D printing [37]

\subsection{Stereolithography (SLA)}

It was patented by Chuck Hull in 1986. SLA technology converts liquid resin into solid materials using high-strength UV light [37]. It is one of the production methods with resin writing machines for production with SLA technology. The working principle is as follows; it is based on hardening by transferring the laser source onto the resin. There are 2 different methods; first, it is known that the process occurs in large printers in this way by projecting the laser source on the resin and hardening the resin and going down the printing table step by step. In the second method, the base of the tank with the resin called the printing tank is covered with a transparent material called fepfilm. By pouring resin material into the printing tank and hardening the laser source of UV rays, the printing surface is lifted and the process is carried out in layers $[37,38,39]$.

SLA technology is one of the most widely used 3D technologies. It is based on the photo-hardening process of a liquid resin in which the liquid resin is placed in a reservoir and a positionally programmed laser is scanned on the resin surface to initiate photopolymerization. The resin hardens and turns from liquid to solid, usually through a chemical crosslinking process [40]. Schematic diagram of the SLA 3D printer shown in Figure 6.

The biggest advantages of SLA method are explained in the following articles [41, 42, 43]:

$\checkmark$ Different material types can be used.

$\checkmark$ Can work with accurate measurements $\checkmark$ High resolution

$\checkmark$ High quality results are obtained while producing with a model with complex and fine details.

$\checkmark$ Fast production

$\checkmark \quad$ Non-hardening resin can be reused

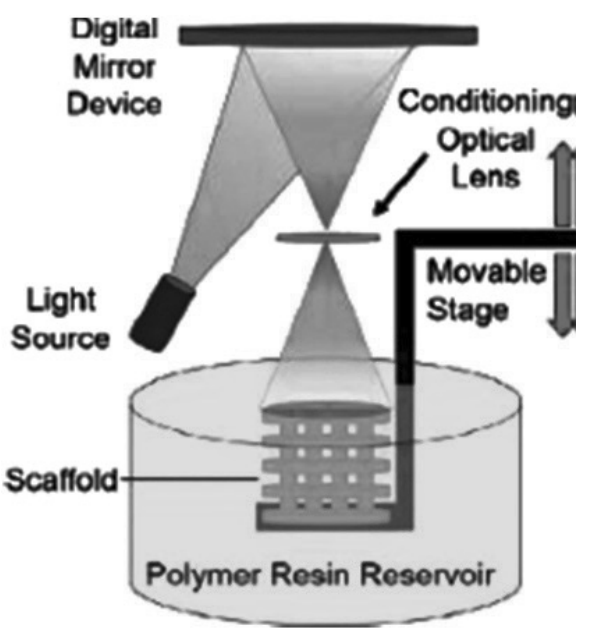

Figure 6: Schematic diagram of SLA 3D printing [37]

One of the disadvantages is that the objects can be fragile. When exposed to sunlight for a long time, degradation may occur because of their low strength. Compared to the FDM method, the SLA method shows higher properties in terms of strength, surface smoothness, stability in production dimensions and production speed. The FDM method is ahead of SLA technology for production volumes and high-volume production. The most used resins range from standard resin, transparent resin, rigid resin, castable resin, flexible resin, elastic resin, high temperature resin shape $[44,45]$.

\subsection{Polyjet}

An Israeli company, Objet Geometries Ltd., The first machine based on Poly-Jet technology was released in early 2000. It has the same working principles as inkjet printing or stereolithography methods. It is in the form of curing the resin with UV rays after the photopolymer resin is sprayed on the surface to be printed. Products with high solubility are produced. Poly-jet systems have the advantage over SLA systems in that the resins come in cartridge form (no liquid photopolymer container), and the devices are clean, quiet, and office-friendly. The parts are less cleaned after the process. Print heads are relatively costly and must be replaced regularly in addition to maintenance costs, this is a disadvantage [46]. With this technology, thin layer production up to $16-32 \mathrm{mi}-$ 
crons can be made [47]. Products with details and fine details can be produced easily. With Polyjet technology, more than one material can be used in production at one time. Thus, it is possible for the material to be both transparent and soft. The support material used is material that can dissolve with liquid [48]. Schematic diagram of the polyjet 3D printer shown in Figure 7.

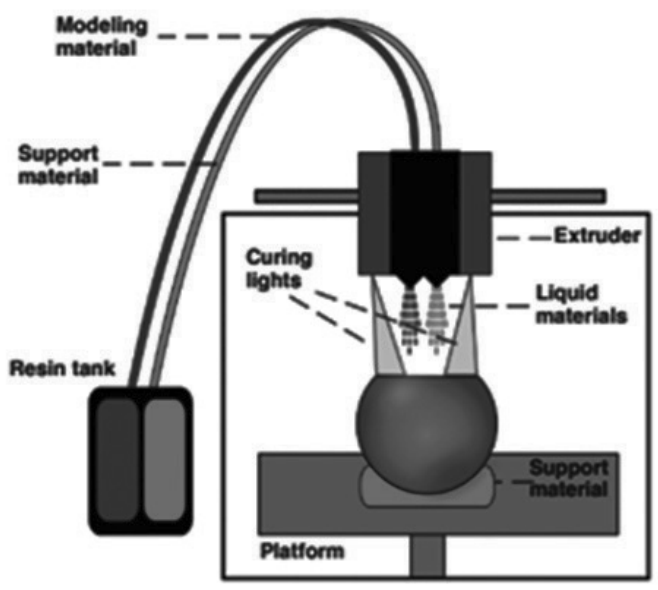

Figure 7: Schematic diagram of polyjet 3D printing [48]
Table 1: Comparison of Polyjet, SLS and FDM technologies $[43,49,50]$

\begin{tabular}{|l|l|l|l|}
\hline & POLYJET & SLS & FDM \\
\hline Solubility & Good & Medium & Weak \\
\hline Strength & Weak & Good & Good \\
\hline Surface quality & Good & Weak & Medium \\
\hline Material & Acrylic & $\begin{array}{l}\text { Polyamide, } \\
\text { polystyrene }\end{array}$ & ABS, PLA \\
\hline
\end{tabular}

\subsection{Binder Jetting}

It is a technology developed by Z corporation. In binder jet technology, known as color 3D printing, as in the SLS method, after the powder material is laid on the printing table, the head of the 3D printer passes over the powder and sprays glue and paint. When the next layer is passed, the powder material spreading process is provided by a roller. After the powder material is spread with the roller, it is completed in this layer by spraying the adhesive and colorant from the head of the printer again and this process is repeat-

Table 2: Production methods, working principles, raw materials in 3D printers [31]

\begin{tabular}{|c|c|c|c|}
\hline $\begin{array}{l}\text { Production } \\
\text { methods }\end{array}$ & Working principle & Raw materials & Example \\
\hline FDM Technology & $\begin{array}{l}\text { It is based on melting } \\
\text { thermoplastic material into thin } \\
\text { layers with nozzle. }\end{array}$ & $A B S$ ve $P L A$ & $\begin{array}{l}\text { The outfit shown at } \\
\text { the Asian art museum } \\
\text { in San Francisco was } \\
\text { printed with PLA. }\end{array}$ \\
\hline SLS Technology & $\begin{array}{l}\text { It is based on hardening resin } \\
\text { powder material in layers. }\end{array}$ & $\begin{array}{l}\text { Polyamide } \\
\text { Polystyrene } \\
\text { Thermoplastic } \\
\text { Elastomer }\end{array}$ & $\begin{array}{l}\text { Iris Van Herpen } \\
\text { and Daniel Widrig's } \\
\text { crystallization } \\
\text { collection suit is } \\
\text { produced using } \\
\text { polyamide material. }\end{array}$ \\
\hline SLA Technology & $\begin{array}{l}\text { It is carried out in the form of } \\
\text { curing UV rays on resin material. }\end{array}$ & Polymer material & $\begin{array}{l}\text { Translucent dress from } \\
\text { Iris Van Herpen's Hybrid } \\
\text { Holism collection. }\end{array}$ \\
\hline $\begin{array}{l}\text { Polyjet } \\
\text { Technology }\end{array}$ & $\begin{array}{l}\text { Curing with UV rays after spraying } \\
\text { photopolymer resin on the surface } \\
\text { to be printed }\end{array}$ & $\begin{array}{l}\text { Multiple raw materials } \\
\text { can be used at the } \\
\text { same time } \\
\text { Multijet materials with } \\
\text { different hardness }\end{array}$ & $\begin{array}{l}\text { Part of Iris Van Herpen's } \\
\text { Ludi Naturae Houte } \\
\text { couture collection, } \\
\text { Foliage dress. }\end{array}$ \\
\hline
\end{tabular}

Binder Jet Technology
As in the SLS method, the adhesive and colorant are based on spraying after placing the powder material on the printing table. 


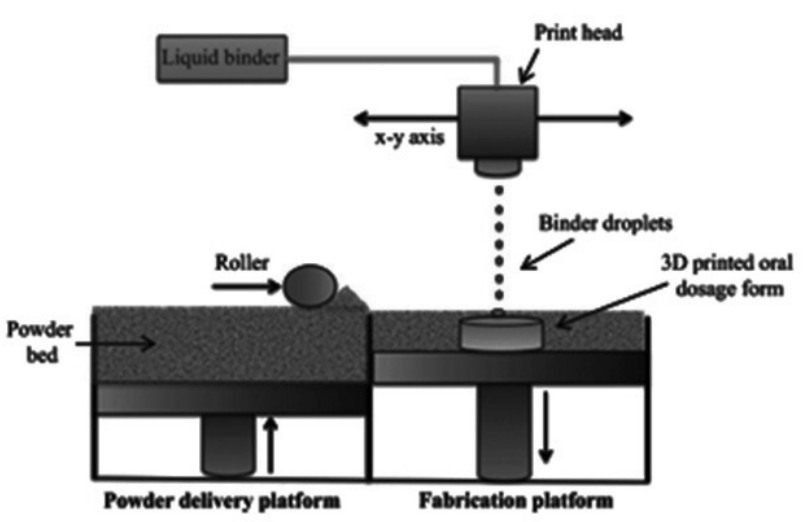

Figure 8: Schematic diagram of binder Jet 3D printer [51]

ed until the model is produced in layers. In order to increase the hardening of the model, it is processed in the oven. No support material is required since it is produced with powder. After the model production is completed, the process is carried out with the help of brush and water in order to remove residual dust. With the binder jet technology, complex shapes can be produced in a very short time and at low cost [51, $52,53]$. The schematic diagram of the binder jet 3D printer is shown in Figure 8.

\subsection{Design Process in 3D Printers}

In additive manufacturing technology, the design process begins with modeling. Modeling is done through scanning or using CAD modeling software.
After the modeling process, the drawings are saved in .stl format. 3D printers have a relatively small building volume. Producing the entire garment in a single production process is difficult. In order to create the final products, small parts need to be assembled. Therefore, it is important to produce the design in smaller parts so that the selected 3D printer matches the allowed structure size. Small parts are combined with suitable adhesives after production. In order to commence production, the parameters of the printers such as layer thickness, strength, speed, temperature, creation of support structures must be determined. Solidworks, AutoCAD, PTC Creo, and Rhinoceros (Rhino 3D) are some examples of commercial CAD software used in engineering, architecture, product design, and industrial design. Solidworks is a hybrid solid and surface modeling application. Rhino 3D makes it easier to work with complex curved surfaces according to SolidWorks, it is more commonly used in 3D design modeling of fashion products where the design includes a large number of curved surfaces $[54,55]$. The stages of the production process, from the development of the idea to the production of the finished product, are shown in Figure 9.

To summarize in general, the design cycle in additive manufacturing begins with an idea in mind. For example, the emergence of an idea such as a collection inspired by motifs in the Seljuk period or objects in nature and sketching and CAD design are made based on this idea [56]. CAD design (Solidworks, Autocad, etc.) the model is saved to a file in .stl format.

Detailed process of a model
1. Conceptual development of the idea.
2. Design of the model in a 3D CAD application.
3. Generation of an .stl or .amf file to enable the
additive manufacturing equipment to interpret
the geometrical information (triangulation)
modelled in $\mathrm{CAD}$.
4. Orientation within the machine and generation
of the NC code (G code) by the additive
manufacturing equipment.
5. Manufacturing of the component.
6. Cleaning. Removal of the support material (if the
technology uses support material and the
component so requires).
7. Post-process phase: (improving the finish and
hardening. Some technologies do not require
this).

Figure 9: Additive manufacturing stages [33] 
Software such as Cura is used to make this file read by a 3D printer. With the selection of materials and printers, the model becomes ready for production [6].

With the 3D printer to be applied, the first step in the production process is the determination of the subject. The subject determined in this study is Anatolian Seljuk Architecture in the 11th and 12th centuries. Anatolian and Seljuk architectural works of this period generally consist of tile, ceramic, wood and stonework. In this way, the subject of the theme research, which is the first step, was inspired by Anatolian and Seljuk architectural works. In the visual research part, the findings such as visual source, texture, form, color in the period were taken into consideration and the basis was prepared for the creation of a storyboard (Figure 10), which is the next stage of the design. There are quite a lot of geometric patterns in Anatolian and Seljuk architecture in the 11th and 12th centuries. The increase in the continuity of geometric patterns took place during the Kara-Khanid Khanate and Great Seljuk Empire period. Seljuk architecture, which has this rich geometric pattern architecture, have reached the borders of Europe with Azerbaijan from Khorasan-Iran, and became more complex patterns with the Anatolian Seljuk Architecture. As a result of research in different sources, geometric patterns and forms in Anatolian and Seljuk Architecture were handled and a storyboard was created. This created panel is realized with Photoshop program. The production area of the product in the 3D printer, which will be produced at this stage, was also considered. This design is manufactured with FDM Ultimaker 2+. The size of the technology's printing table has a surface area of $23 \times 23 \times 20$ $\mathrm{cm}$. The numerical data is formed to produce the model garment not in one piece but in a form divided into parts [6].

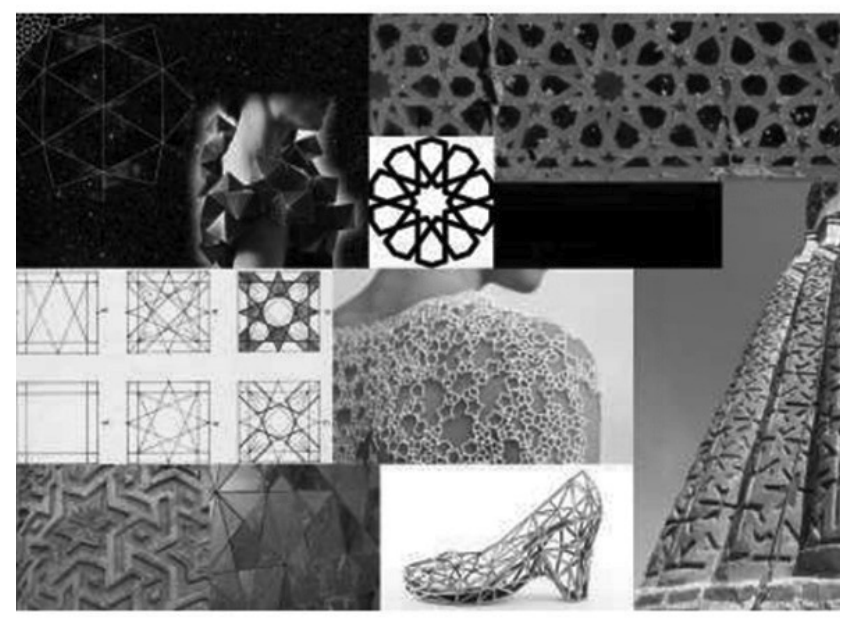

Figure 10: Storyboard [6]

\section{FILAMENTS USED IN 3D PRINTERS IN THE FASHION INDUSTRY}

The materials required by 3-D printers are thermoplastics that can be processed at medium temperature and pressure. Acrylonitrile butadiene styrene (ABS), nylon, polycarbonate (PC), high density polyethylene (HDPE), high impact polystyrene (PS) and polylactic acid (PLA), polyethylene terephthalate (PET) filaments are used for the development of products in fashion industry such as clothes, jewelry, shoes, etc. The most popular filament materials among them are ABS, PLA and PET $[57,58]$.

\subsection{Polylactic acid (PLA)}

It is one of the most widely used filament types in 3D printing. It is environmentally friendly as it is of organic origin and does not consist of petrochemicals. It is obtained from edible sources such as corn and sugar cane. It is biodegradable and it has good strength. In the printing process, the process can be facilitated by a fan placed next to the printing table in order to cool the PLA material. In addition, the fans used can also improve the surface quality. Using the PLA material can provide more flexibility than other thermoplastic materials. More $\mathrm{CO} 2$ emissions occur. It is more brittle than $A B S$ and more flexible than nylon $[57,58$, $59,60]$. The glass transition temperature of PLA is $60^{\circ}$ $C$. The temperature to be used for $3 \mathrm{~d}$ printing with PLA is $210^{\circ} \mathrm{C}$. At higher temperature, it begins to deteriorate [58].

\subsection{Acrylonitrile Butadiene Styrene (ABS)}

ABS filament is often used in 3D printer [58]. ABS is a derivative of petroleum, and it is considered toxic. So it is not environmentally friendly like PLA [57]. However, the glass transition temperature is much higher. ABS is an ideal choice for parts and objects that will be exposed to temperatures up to $100^{\circ} \mathrm{C}$. $A$ heated structure platform is required for $A B S$ to be used in a 3D printer. A minimum temperature of 100 ${ }^{\circ} \mathrm{C}$ is required for the platform and $240^{\circ} \mathrm{C}$ is required for the extrusion nozzle. Natural ABS is off-white. But with some techniques for PLA, it can be processed as transparent or color during manufacturing. It melts at a higher temperature than PLA $\left(150^{\circ} \mathrm{C}\right)$, but it binds better between $220-225^{\circ} \mathrm{C}$. It is more easily extruded than PLA. [58]. In addition, it emits a bad odor to the environment during printing, so the environment needs to be ventilated [60]. 


\subsection{Polyethylene Terephthalate (PET)}

Polyethylene terephthalate is an odorless, colorless, impact resistant filament that is derived from polyester. The extrusion temperature of PET is between $210^{\circ} \mathrm{C}$ and $224^{\circ} \mathrm{C}$. There is no need for a heated build plate [61]. PET is the most recycled plastic among all plastics [62]. Although PET filament is normally a colorless material, its colorlessness changes when heated or cooled [63].

\section{CONCLUSION}

It is now easier for designers in the fashion industry to embody original ideas thanks to $3 \mathrm{D}$ printing technologies. 3D printers take the fashion world to another dimension. Mold making, which takes time in the fashion industry, is being replaced by CAD software. With CAD software, measurements of a live model can be transferred to a computer within a few minutes. Also, changes can be made to an existing design and production can be started within seconds. Thanks to this technology, the consumer has become his own designer and manufacturer. Unique designs can be made with the help of 3D printers that use the correct filament while weaving, knitting and non-woven surfaces are obtained with yarn. The designs are used in daily life and help reveal our imagination in fashion shows. Today, these designs can be made with $3 \mathrm{D}$ printers. One of the advantages of 3D printers is mass production and recycling. Raw materials used in printers can be recycled. It is known as a technology that sheds light on the sustainability that is today's problem. This technology allows people to make their own designs in seconds. Also, pollution that occurs at the end of production in factories can be prevented. Besides the advantages of 3D printers, it has a disadvantage, such as the problem of raw materials. Synthetic raw materials cannot provide the soft feeling of textile products used in daily life. However, it is believed that this disadvantage can be eliminated with innovations in the coming days.

\section{REFERENCES}

[1] Drew, L., Sinclair, R. (2015). Fashion and the Fashion Industry, Textiles and Fashion: Materials, Design and Technology, Woodhead Publishing, Elsevier, Cambridge.

[2] Reilly A. (2021). Introducing Fashion Theory: From Androgyny to Zeitgeist, Bloomsbury Publishing, London.
[3] What is fashion design? (https://www.fibre2fashion. com/industry-article/2860/what-is-fashion-design, available: 16.04.2021).

[4] Calderin, J. (2013). Fashion History, The Fashion Design Reference + Specification Book, Rockport.

[5] Waddell, G. (2004). Ready-to-Wear, How Fashion Works: Couture, Ready-to-Wear and Mass Production, Blackwell Publishing.

[6] Zaimoğlu, Ö., Yıldıran, M. (2017). Moda tasarımında inovatif bir yöntem: üç boyutlu yazıcılar ile giysi tasarımı uygulamaları, 6 (8), 2949-2976.

[7] Yıldıran, M. (2016). Moda giyim sektöründe üç boyutlu yazıcılarla tasarım ve üretim, Süleyman Demirel Üniversitesi Güzel Sanatlar Fakültesi Hakemli Dergisi 9(17),155-172.

[8] Düzgün, D.E., Çetinkaya, K. (2019). Moda alanında üç boyutlu baskı teknolojileri kullanımı, International Journal of 3D Printing Technologies and Digital Industry, 3 (1), 19-31.

[9] Yıldıran, M. (2016). Üç boyutlu yazıcılarla moda ürünlerinde kütlesel kişiselleştirme, Akdeniz Sanat Degisi, 9 (19) 29-47.

[10] Greenhalgh, S. (2016). The effects of 3D printing in design thinking and design education, Journal of Engineering, Design and Technology, 14 (4), 752-769.

[11] Vanderploeg, A., Lee, S.E., Mamp, M. (2016). The application of 3D printing technology in the fashion industry, International Journal of Fashion Design, Technology and Education, 12 (51), 1-7.

[12] Zou, S., Xiao, J., Ding, T., Duan, Z., Zhang, Q. (2021). Printability and advantages of 3D printing mortar with $100 \%$ recycled sand, Construction and Building Materials, 273, 1-6.

[13] Attaran, M. (2017). The rise of 3-D printing: The advantages of additive manufacturing over traditional manufacturing, Business Horizons, 60, 677-688.

[14] Lipson, H., Kurman, M. (2013). Fabricated: The New World of 3D Printing, Wiley, New York.

[15] Pasricha, A., Greeninger, R. (2018). Exploration of $3 \mathrm{D}$ printing to create zero-waste sustainable fashion notions and jewelry, Fashion and Textiles, 5 (30), 1-18.

[16] Pashkevich, K., Dyachenko, I., Protsyk, B., Zelenska, V. (2020), Innovations in the technology of 3D printing of fashion goods, Актуальні проблеми сучасного дизайну, 1-3. 
[17] Daanen, H.A.M., Psikuta, A. (2018). 3D Body Scanning, Automation in Garment Manufacturing, Woodhead Publishing, Elsevier, Cambridge.

[18] Janne Kyttanen (https://www.jannekyttanen.com /case-studies/dress-and-lost-luggage, available: 16.04.2021).

[19] 3D-printed dress for Dita Von Teese by Michael Schmidt and Francis Bitonti (https://www.dezeen. com/2013/03/07/3d-printed-dress-dita-vonteese-michael-schmidt-francis-bitonti/, available: 16.04.2021).

[20] Trust, T., Maloy, R. W. (2017). Why 3D print? The 21st-century skills students develop while engaging in $3 \mathrm{D}$ printing projects, Computers in the Schools, 34 (4), 253-266.

[21] Horvath, J. (2014). A Brief History of 3D Printing, Mastering 3D Printing, Apress.

[22] Roopavath, U.K., Kalaskar, D.M. (2017). Introduction to $3 D$ printing in medicine, $3 D$ Printing in Medicine, Woodhead Publishing, Elsevier, Cambridge.

[23] Su, A., Al'Aref, S. J. (2018). History of 3D Printing, 3D Printing Applications in Cardiovascular Medicine, Academic Press, Elsevier, Cambridge.

[24] 3D printing market - Growth, trends, covid-19 impact, and forecasts (2021-2026) (https://www. mordorintelligence.com/industry-reports/3dprinting-market, available: 16.04.2021).

[25] Partsch, L.N., Vassiliadis, S., Papageorgas, P. (2015). 3D Printed Textile Fabrics Structures, 3D Printed Textile Fabrics Structures. In: 5th International Istanbul Textile Congress, Istanbul, Turkey.

[26] Nervous System (https://n-e-r-v-o-u-s.com/ projects/sets/kinematics/, available: 16.04.2021).

[27] Ukobitz, D., Faullant, R. (2021). Leveraging 3D printing technologies: The case of Mexico's footwear industry, Research-Technology Management, 64 (2), 20-30.

[28] Valtas, A., Sun, D. (2016). 3D printing for garments production: An exploratory study, Journal of Fashion Technology \& Textile Engineering, 4 (3), 1-4.

[29] Awad, A., Fina, F., Goyanes, A., Gaisford, S., Basit, A.W. (2020). 3D printing: Principles and pharmaceutical applications of selective laser sintering, International Journal of Pharmaceutics, 586, 1-12.

[30] Kim, S., Seong, H., Her, Y., Chun, J. (2019). A study of the development and improvement of fashion products using a FDM type 3D printer, Fashion and Textiles, 6 (9).
[31] Şahin, K., Turan, B. O. (2018). Üç boyutlu yazıcı teknolojilerinin karşılaştııımalı analizi, Stratejik ve Sosyal Araştırmalar Dergisi, 2 (2), 98-116.

[32] Iris Van Herpen (https://www.irisvanherpen.com/ available: 16.04.2021).

[33] Jiménez, M., Romero, L., Dominguez, I.A., del Mar Espinosa, M., Dominguez, M. (2019). Additive manufacturing technologies: An overview about 3D printing methods and future prospects, Complexity, $1-30$.

[34] Mazzanti, V., Malagutti, L., Mollica, F. (2019). FDM $3 \mathrm{D}$ printing of polymers containing natural fillers: A review of their mechanical properties, Polymers, 11, 1-22.

[35] Chakraborty, S., Biswas, M.C. (2019). Fused deposition modeling 3D printing technology in textile and fashion industry: Materials and innovation, Modern Concepts in Material Science, 2 (1), 1-5.

[36] 3D printed fashion: Why is additive manufacturing interesting for fashion? (https://www.sculpteo. com/blog/2018/01/24/3d-printed-fashion-why-isadditive-manufacturing-interesting-for-fashion/, available: 16.04.2021).

[37] Singh, S., Ramakrishna, S., Berto, F. (2020). 3D Printing of polymer composites: A short review, Wiley, 1-13.

[38] Sheikh, J. A., Waheed, M. F., Khalid, A. M., \& Qureshi, I. A. (2019). Use of 3D printing and nano materials in fashion: From revolution to evolution, Advances in Design for Inclusion, 422-429.

[39] Chakraborty, S. Biswas, M.C. (2020). 3D printing technology of polymer-fiber composites in textile and fashion industry: A potential roadmap of concept to consumer, Composite Structures, 248, 1-13.

[40] Ge, Q., Li, Z., Wang, Z., Kowsari, K., Zhang, W., He, X., Zhou, J., Fang, N. X., (2020). Projection micro stereolithography based $3 \mathrm{D}$ printing and its applications, International Journal of Extreme Manufacturing, 1-19.

[41] Manapat, J. Z., Chen, Q., Ye, P., Advincula, R.C. (2017). 3D Printing of polymer nanocomposites via stereolithography, Macromolecular Materials and Engineering, 302, 1-13.

[42] Wang, J., Goyanes, A., Gaisford, S., Basit, A.W., (2016). Stereolithographic (SLA) 3D printing of oral modified-release dosage forms, International Journal of Pharmaceutics, 503, 207-212. 
[43] Bandyopadhyay, A., Bose, S., Das, S., Editors, G. (2015). 3D Printing of biomaterials, MRS Bulletin, 40 (2), 108-115.

[44] FDM vs. SLA 3D yazıcı teknolojileri karşılaştııılması (https://www.boyutkat.com/3d-yazici/fdm-sla3d-yazici-karsilastirma/\#fdm-ve-sla-teknolojisinedir $\% 20 \% 201 \% 20$ dergipark, available: 16.04.2021).

[45] SLA (Stereolithography) 3D baskı teknolojisi (https://3d3teknoloji.com/sla-3d-baski-teknolojisi/, available: 16.04.2021).

[46] Ramya, A., Vanapalli, S.L. (2016). 3D Printing technologies in various applications, International Journal of Mechanical Engineering and Technology, 7 (3), 396-409.

[47] Meisel, N.A., Williams, C.B. (2014). Design for additive manufacturing: An investigation of key manufacturing considerations in multi-material polyjet 3D printing, In Proceedings of the 25th Annual international solid freeform fabrication Symposium, Austin (TX), USA, 746-763.

[48] Groth, C., Kravitz, N.D., Jones, P.E., Graham, J. W., Redmond, W. R. (2014). Three-dimensional printing technology, JCO, 48 (8), 475-485.

[49] Kudelski, R., Cieslik, J., Kulpa, M., Dudek, P., Zagorski, K., Rumin, R. (2017). Comparison of cost, material and time usage in FDM and SLS 3D printing methods, MEMSTECH, 20-23.

[50] Kluska, E., Gruda, P., Majca-Nowak, N. (2018), The accuracy and the printing resolution comparison of different 3d printing technologies, Transactions on Aerospace Research, 3 (252), 69-83.

[51] Trenfield, S. J., Madla, C. M, Basit, A.W., Gaisford, S. (2018). Binder Jet Printing in Pharmaceutical Manufacturing, 3D Printing of Pharmaceuticals, Springer, Cham.

[52] Mostafaei, A., Elliott, A.M., Barnes, J. E., Li, F., Tan, W., Cramer, C. L., Nandwana, P., Chmielus, M. (2020). Binder jet 3D printing-Process parameters, materials, properties, modeling, and challenges, Progress in Materials Science, 1-138.

[53] Gilmer, D., Han, L., Hong, E., Siddel, D., Kisliuk, A., Cheng, S., Brunermer, D., Elliott, A., Saito, T. (2020). An in-situ crosslinking binder for binder jet additive manufacturing, Additive Manufacturing, 35, 1-11.

[54] Yap, Y.L., Yeong, W.Y. (2014). Additive manufacture of fashion and jewellery products: a mini review, Virtual and Physical Prototyping, 9 (3), 195-201.
[55] Mijovic, B., Ujević, D. (2016), The use of 3D printers in shoe technology, Textile Science and Economy VIII 8th International Scientific-Professional Conference, Zrenjanin, Serbia, pp.55-58.

[56] 5 mistakes to avoid when designing a 3D model for 3D printing (https://i.materialise.com/blog/ en/5-mistakes-to-avoid-when-designing-a-3dmodel-for-3d-printing/, /, available: 16.04.2021).

[57] Zhao, X.G., Hwang, K.J., Lee, D., Kim, T., Kim, N. (2018). Enhanced mechanical properties of selfpolymerized polydopamine-coated recycled PLA filament used in 3D printing, Applied Surface Science, 441, 381-387.

[58] Horne, R., Hausman, K.K. (2017). 3D Printing for Dummies, John Wiley \& Sons, Hoboken.

[59] Ardiansyah, R.; Rusita, L.; Larasati, I.L.; Nugroho, A. (2018), Effect of layer thickness on flexural properties of PLA (PolyLactid Acid) by 3D printing, Journal of Physics: Conference Series, 1130, 1-10.

[60] Kamran, M., Saxena, A. (2016). A comprehensive study on 3D printing technology, MIT International Journal of Mechanical Engineering, 6 (2), 63-68.

[61] McMills, A.E. (2017). 3D Printing Basics for Entertainment Design, Routledge, New York.

[62] Fisher, G. (2013). Blender 3D Printing Essentials, Packt Publishing, London.

[63] Wojtyła, S., Klama, P., Baran, T. (2017), Is 3D printing safe? Analysis of the thermal treatment of thermoplastics: ABS, PLA, PET, and, nylon, Journal of Occupational and Environmental Hygiene, 14(6), D80-D85.

Primljeno/Received on: 16.04.2021.

Revidirano/ Revised on: 30.05.2021.

Prihvaćeno/Accepted on: 01.06.2021.

(c) 2021 Authors. Published by Union of Textile Engineers and Technicians of Serbia. This article is an open access article distributed under the terms and conditions of the Creative Commons Attribution 4.0 International license (CC BY) (https://creativecommons.org/licenses/ by/4.0/) 